1 London School of Hygiene and Tropical Medicine, London, UK

2 Carlo F Dondena Centre for Research on Social Dynamics and Public Policy, Bocconi University. Milan, Italy

Martin.McKee@lshtm.ac.uk Cite this as: BMJ 2020;371:m4024 http://dx.doi.org/10.1136/bmj.m4024 Published: 19 October 2020

\section{Scientific divisions on covid-19: not what they might seem}

\section{It is not whether we should open up or lock down. Rather, it's how we can break the chain of transmission, argue Martin McKee and David Stuckler}

Martin McKee, ${ }^{1}$ David Stuckler ${ }^{2}$

A new theme has emerged in the media discourse on covid-19 in the UK. We are told that the scientific community is divided, between those who advocate stringent lockdowns even at the cost of widespread collateral damage to mental and physical health, and those who propose returning rapidly to life as normal, allowing the virus to spread through the population. ${ }^{1}$ Yet this is a false dichotomy. Most experts who support restrictions do so as a last resort, only to interrupt the exponential growth in infections that would occur if transmission was unchecked. And those who oppose restrictions concede that allowing the virus to spread could only apply to a proportion of the population who, in their view, faced limited risk.

This is not to say that there are no divisions. While most scientists recognise that there are difficult choices to make, with no easy answers, a small group takes a much more extreme view. Those who drafted the Great Barrington Declaration argue that we should actively encourage the spread of the virus as a means of achieving herd immunity while adopting "focused protection" of those deemed vulnerable. ${ }^{2}$ As set out in detail in a letter to the Lancet, this proposal is deeply flawed and its proponents have failed to provide any details of the practicalities involved in isolating what could be up to $40 \%$ of the population once those who care for vulnerable people are included. ${ }^{3}$ The president of the UK Academy of Medical Sciences has described these proposals as "unethical and simply not possible," a view echoed by the director general of the World Health Organization, while the chief executive of NHS England has used the term "apartheid" to emphasise how truly radical the proposals are..$^{-6}$

Yet, while the case for actively pursuing herd immunity by allowing the virus to spread lacks credibility, there are many well meaning scientists and health professionals who have supported the Great Barrington Declaration. This is concerning because it promotes the view that the scientific community is fractured into two large competing groups, undermining trust in science. Some commentators have noted the similarity with the manufacture of doubt in the climate change or second hand smoking debates. They point to the previous activities of some of the powerful business and political interests that have been linked to the declaration that have long promoted a neoliberal agenda of low taxes and small government, and have prioritised individual freedom over social solidarity. ${ }^{7}$

The concerns of many of the real people (many names have been found to be fictitious) who have signed the declaration are understandable. ${ }^{8}$ Indeed they are shared with many of those who are portrayed as being in opposition to them. It is difficult to imagine that anyone would consider the damage to education, to incomes, and to mental and physical health as acceptable. ${ }^{9}$ Yet, it is also unacceptable to allow the virus to proceed unchecked even if there was some way of protecting the "vulnerable."

If these two statements are accepted, then it suggests that many have been asking the wrong question. It is not whether we should open up or lock down. Rather, it is how we can break the chain of transmission while protecting those who are harmed by isolation.

Fortunately, we can find answers. While area-wide lockdowns were necessary at the start of the pandemic when little was known about the virus, they are blunt instruments. Countries, such as Taiwan and Korea, with well functioning find, test, and trace systems have been able to use backwards contract tracing to identify the sources of infection and act against them. ${ }^{10}$ Yet, in England local politicians are still asking in vain for evidence to justify restrictions on hospitality venues while the centralised and deeply dysfunctional tracing system cannot provide the answers. ${ }^{11}$ Even if the local models of tracing using this approach were adequately resourced, they would struggle with the volume of cases now occurring. England's troubles are now deeper and structural. One reason that the UK lost control is the large number of people who are not isolating, but should (only 19\% of those required to isolate are estimated to have done so as intended). ${ }^{12}$ This, in turn, reflects the growth of precarious income, employment, and housing, coupled with inadequate support for those unable to work. Although portrayed as generous, the UK's support for those struggling during the pandemic is less generous than that in Canada, Germany, Japan, and even the US. ${ }^{12} 13$

The solution is, in itself, not a scientific problem but a political one. All these approaches would involve a sustained investment in public services. They would recognise that public health staff in local government will do a far better job than large corporations with no relevant experience. They would accept that the social safety nets eroded by a decade of austerity would have to be fixed. ${ }^{14}$ But these measures would be unacceptable to the powerful backers of some of those who are so highly visibly promoting a model that seeks to restore corporate profits while locking up a substantial share of the population.

Competing interests: MM is a member of the Independent SAGE and research director of the European Observatory on Health Systems and Policies, which manages the Covid Health Systems Response Monitor. MM and DS are signatories 
1 Harford T. Lockdown sceptics v zero-covid: who's got it right? Financial Times. 2020. www.ft.com/content/0143a8b8-d32b-46e0-bd84-f152bb9df2d7.

2 Great Barrington Declaration. 2020. https://gbdeclaration.org.

3 Alwan NA, Burgess RA, Ashworth S, et al. Scientific consensus on the covid-19 pandemic: we need to act now. Lancet 2020;15. doi: 10.1016/S0140-6736(20)32153-X

4 Lechler R. Navigating covid-19 through the volume of competing voices. Academy of Medical Sciences. 9 October 2020. https://acmedsci.ac.uk/more/news/navigating-covid-19-through-thevolume-of-competing-voices.

5 UN News. Herd immunity, an "unethical” covid-19 strategy, Tedros warns policymakers. 2020. https://news.un.org/en/story/2020/10/1075232.

6 Cambell D. Asking over-65s to shield is "age based apartheid," boss of NHS England says. Guardian. 28 September 2020. www.theguardian.com/society/2020/sep/28/asking-over-65sto-shield-is-age-based-apartheid-nhs-england-boss-says-covid.

7 Ahmed N. Climate science denial network behind Great Barrington declaration. 2020. https://bylinetimes.com/2020/10/09/climate-science-denial-network-behind-great-barringtondeclaration.

$8 \quad$ Herd immunity letter signed by fake experts including “Dr Johnny Bananas.” Guardian. 9 October 2020. www.theguardian.com/world/2020/oct/09/herd-immunity-letter-signed-fake-experts-drjohnny-bananas-covid.

9 Douglas M, Katikireddi SV, Taulbut M, McKee M, McCartney G. Mitigating the wider health effects of covid-19 pandemic response. BM/2020;369:m1557. doi: 10.1136/bmj.m1557 pmid: 32341002

10 Rajan S, D Cylus J, Mckee M. What do countries need to do to implement effective 'find, test, trace, isolate and support' systems?] R Soc Med 2020;113:245-50. doi: 10.1177/0141076820939395 pmid: 32663428

11 Coronavirus: Liverpool faces “tier three” lockdown-pubs, bars and gyms expected to close. Sky News. 2020. https://news.sky.com/story/coronavirus-liverpool-faces-tier-3-lockdown-pubs-barsand-gyms-expected-to-close-12101965.

12 Smith LE, Potts HWW, Amlot R, Fear NT, Michie S, Rubin J. Adherence to the test, trace and isolate system: results from a time series of 21 nationally representative surveys in the UK (the Covid-19 Rapid Survey of Adherence to Interventions and Responses [CORSAIR] study). medRxiv 2020.09.15.20191957 [preprint] 2020 www. medrxiv.org/content/10.1101/2020.09.15.20191957v1.article-metricsdoi: 10.1101/2020.09.15.20191957.

13 Emmerson C, Stockton I. How does the size of the UK's fiscal response to coronavirus compare with other countries'? Institute for Fiscal Studies. 14 May 2020. www.ifs.org.uk/publications/14845.

14 Hiam L, Dorling D, McKee M. Things fall apart: the British health crisis 2010-2020. Br Med Bull 2020;133:ldz041. doi: 10.1093/bmb/ldz041 pmid: 32219417 